\title{
KONSEP EKONOMI IBNU KHALDUN DAN AL-CHAZALI
}

Nur Asia (901001180963)

\section{A. Konsep Ekonomi lbnu Khaldun}

Sebuah kitab yang sangat menakjubkan, karena isinya mencakup berbagai aspek ilmu dan kehidupan manusia pada ketika itu. Salah satu karya fenomenal Ibnu Khaldun adalah Kitab Al -Muqaddimah, yang selesai penulisannya pada Nopember 1377. ' Al-Muqaddimah secara harfiah bararti 'pembukaan' atau 'introduksi' dan merupakan jilid pembuka dari tujuh jilid tulisan sejarah. Al-Muqaddimah mencoba untuk menjelaskan prinsip-prinsip yang menentukan kebangkitan dan keruntuhan dinasti yang berkuasa (daulah) dan peradaban ('umran). Tetapi bukan hanya itu saja yang dibahas. Al-Muqaddimah juga berisi diskusi ekonomi, sosiologi dan ilmu politik, yang merupakan kontribusi orisinil Ibnu Khaldun untuk cabang-cabang ilmu tersebut. Ibnu Khaldun juga layak mendapatkan penghargaan atas formula dan ekspresinya yang lebih jelas dan elegan dari hasil karya pendahulunya atau hasil karya ilmuwan yang sejaman dengannya. Melahirkan karya Al-Muqaddimah menjadikan lbnu Khaldun sebagai seorang genius polymath (jenius dalam berbagai bakat) dan seorang renaissance man yang menguasai banyak bidang ilmu. Di dalam kitab ini, Ibnu Khaldun membincangkan berbagai topik seperti sejarah, geografi, matematik, agama, sistem kerajaan, sistem ekonomi, sistem pendidikan dan lain-lain.

Ibnu Khaldun hidup di jaman di mana mata uang sudah menjadi alat penghargaan. Pada masa itu ia sudah membicarakan kemungkinan yang bakal terjadi tentang kedudukan yang selanjutnya dari mata uang. Dia menulis sebagai berikut:

"Sesudah demikian, Allah telah menjadikan pula dua barang galian yang berharga, ialah emas dan perak menjadi bernilai di dalam perhubungan ekonomi. Keduanya menurut kebiasaan menjadi alat perhubungan dan alat simpanan bagi penduduk dunia. Jika terjadi alat perhubungan dengan yang lainnya pada beberapa waktu, maka tujuan yang utama tetap untuk memiliki kedua benda itu di dalam peredaran harga-harga pasar, karena keduanya terjauh dari pasar itu" ${ }^{2}$

Akhirnya Ibnu Khaldun meramalkan bahwa kedua barang galian ini nanti akan mengambil tempat yang terpenting di dalam dunia perekonomian, ialah melayani tiga kepentingan, yaitu: pertama, menjadi alat penukar dan pengukur harga, sebagai nilai usaha (makasib); kedua, menjadi alat perhubungan, seperti deviezen (qaniah); dan ketiga, menjadi alat simpanan di dalam bank-bank (zakhirah).

Inilah analisa Ibnu Khaldun sewaktu emas dan perak baru merupakan dinar dan dirham. Dia sudah mengetahui bahwa dengan secepatnya dunia akan meninggalkan zaman natural wirschift (tukar menukar barang), berpindah kepada jaman modern yang lebih terkenal dengan "geld wirschiff" (jual beli dengan perantaraan uang). Dalam jaman baru itu, emas dan perak akan menempati tempatnya "ukuran nilai" (standaard).

\footnotetext{
${ }^{1}$ Choirun Huda, Pemikiran Ekonomi Bapak Ekonomi Islam; Ibnu Khaldun, Jurnal Economica, 2013, vol. 4. No.1
} 


\section{B. Konsep Ekonomi Al-Chazali}

Perhatian al-Cazali terhadap kehidupan masyarakat tidak terfokus pada satu bidang tertentu, tetapi meliputi aspek kehidupan manusia. la melakukan studi keislaman secara luas untuk mempertahankan ajaran agama Islam. Oleh karena itu, kita tidak menemukan sebuah karya tulisnya yang khusus membahas ekonomi Islam. Perhatiannya di bidang ekonomi itu terkandung dalam berbagai studi fiqihnya, karena ekonomi Islam, pada hakikatnya merupakan bagian yang tak terpisahkan dari fiqih Islam. ${ }^{3}$ Namun demikian, pemikiran-pemikiran ekonomi alCazali didasarkan pada pendekatan tasawuf, karena masa hidupnya, orang-orang kaya, berkuasa, dan sarat prestise sulit menerima pendekatan fiqih dan filosofis dalam mempercayai Yaum- alHisab.

Dalam pandangan al-Cazali, pasar harus berfungsi berdasarkan etika dan moral para pelakunya. Secara khusus, ia memperingatkan lantaran mengambil keuntungan dengan cara menimbun makanan dan barang-barang kebutuhan dasar lainnya. Penimbunan barang merupakan kezaliman yang besar, terutama di saat-saat terjadi kelangkaan, dan pelakunya harus dikutuk.21 Selain itu, al-Cazali bersikap sangat kritis terhadap laba yang berlebihan.

Secara khusus, al-Gazali memandang bahwa produksi barang-barang kebutuhan dasar sebagai kewajiban sosial. Hal ini berarti, jika telah ada sekelompok orang yang berkecimpung di dunia usaha yang memproduksi barang-barang tersebut dalam jumlah yang mencukupi kebutuhan masyarakat, maka kewajiban seluruh masyarakat telah terpenuhi. Namun, jika tidak ada seorang pun yang melibatkan diri dalam kegiatan tersebut atau jika jumlah yang diproduksi tidak mencukupi kebutuhan masyarakat, semua orang akan dimintai pertanggungjawabannya di akhirat. Dalam hal ini, pada prinsipnya negara harus bertanggng jawab dalam menjamin kebutuhan masyarakat terhadap barang-barang kebutuhan pokok.

Al-Cazali mempunyai wawasan yang sangat luas dan mendalam tentang berbagai kesulitan yang timbul dari pertukaran barter dari satu sisi, disisi lain signifikansi uang dalam kehidupan manusia. Sebelumnya telah dikemukakan bagaimana tidak efisiennya jika dilakukan sistem barter. la pun menegaskan bahwa evolusi uang terjadi hanya kesepakatan dan kebiasaan, yakni tidak akan ada masyarakat tanpa pertukaran barang dan tidak ada pertukaran yang efektif tanpa ekuivalensi, dan ekuivalensi demikian hanya dapat ditentukan dengan tepat bila ada ukuran yang sama.

\footnotetext{
${ }^{3}$ Sirajuddin, Konsep Pemikiran Ekonomi Al-Ghazali, Jurnal Laa Maisyir, 2016, 3.1.
} 


\section{DAFTAR PUSTAKA}

Huda Choirun, Pemikiran Ekonomi Bapak Ekonomi Islam; Ibnu Khaldun, Jurnal Economica, 2013, vol. 4. No.1

Sirajuddin. 2016. Konsep Pemikiran Ekonomi Al-Ghazali. Jurnal Laa Maisyir. Vol.3.No.1. 